\title{
Viral Hepatitis C (HCV) in Hemodialysis
}

\section{Seba Atmane}

Department of Nephrology, University Hospital Tizi Ouzou, ALGERIA

Correspondence: Seba Atmane, Department at University Hospital Tizi Ouzou, Algeria.

Received Date: June 08, 2020; Accepted Date: June 23, 2020; Published Date: June 26, 2020.

Citation: Atmane S, (2020) Viral Hepatitis C (HCV) in Hemodialysis. Journal of Clinical Case Reports and Studies, 1(2): Doi: 10.31579/26908808/009

Copyright: (C2020.Seba Atmane. This is an open-access article distributed under the terms of the Creative Commons Attribution License, which permits unrestricted use, distribution, and reproduction in any medium, provided the original author and source are credited.

\section{Abstract}

The aim of the study is to show the prevalence and risk factors of HCV at our hemodialysis (HD) center, in a study carried out on chronic hemodialysis patients during the year 2019, we identified eight cases out of 87 patients infected with $\mathrm{HCV}$, or $9 \%$. The average age in this population is 48 years, dialysed for an average of 15 years. Viral infection was discovered on average 12.5 years after the start of hemodialysis, during a routine screening examination. In this series, the genotype $1 \mathrm{~b}$ was found in 2 cases $(25 \%)$. Seven patients were treated out of the eight HCV hemodialysis patients, received dual therapy with sofosbuvir $400 \mathrm{mg}$ and daclar $60 \mathrm{mg}$ for three months, with an early virologic response. A study done during a previous period, between 2015 and 2018, in the same center, looking at the risk factors for HCV transmission: 11 cases out of 134 hemodialysis patients infected with HCV. Among these cases, we noted the following factors; Blood transfusion: 3 cases (27.2\%), surgery: 4 cases (45.4\%), dental care: 2 cases (18\%), no obvious cause: 2 cases (9\%). Serologically ; HCV antibodies positive: 11/134, i.e. an 8.2\% seroprevalence, PCR-viral RNA was positive in 10 out of 11 patients, i.e. a prevalence of $7.4 \%$ by PCR, number of copies: Above 1.03x 1, 000,000 (100\%), number of Logs: Sup to 3.32 (100\%), negative PCR: 01 patient.

Key Words: hepatitis $\mathrm{C}$ virus; Chronic hemodialysis

\section{Introduction}

Viral hepatitis $\mathrm{C}$ common in hemodialysis patients is the main viral infection, its prevalence ranges from 11 to $60 \%$. Africa has the highest prevalence of hepatitis $\mathrm{C}$ virus infection Patients on HD are at high risk for $\mathrm{HCV}$, with frequency of infection several times higher than that in non-uremic patients [1]. Its seriousness lies in the high risk of progression to chronicity and the development of cirrhosis or hepatocarcinoma. The hepatitis $\mathrm{C}$ virus (HCV) is an RNA virus. There are six groups, called genotypes from [1 to 6], and more than a hundred subtypes (1a, 1b ...).There are multiple transmission routes; blood path, genital, motherchild, medical procedures: digestive endoscopies, dialysis. Any material that may be in contact with the blood, reusable and poorly sterilized, can transmit the virus, hence the obligation to use single-use equipment. Dental care, acupuncture sessions if the needles are not disposable. Shaving, tattoos, ear piercing.

\section{Study goals:}

The aim of the study is to show the prevalence and risk factors of HCV at the hemodialysis center.

\section{Methods:}

The systematic virological assessment: before the start of dialysis sessions, then again every 03 -06 months (microbiology laboratory). HCV antibodies using the Elisa 3 Architect i 2000 SR technique, specificity: 99.6\%.VHC PCR with the Cobas Ampli Pre'p / Cobas Taq Man VHCtest1 kit, performed in patients (antibody VHC +), sensitivity: 99.1\%. In addition to detecting HCV RNA, HCV genotyping is also required to predict response to treatment and to specify the duration and dosage of treatment. The Fibroscan assessment: carried in the hepatology department.

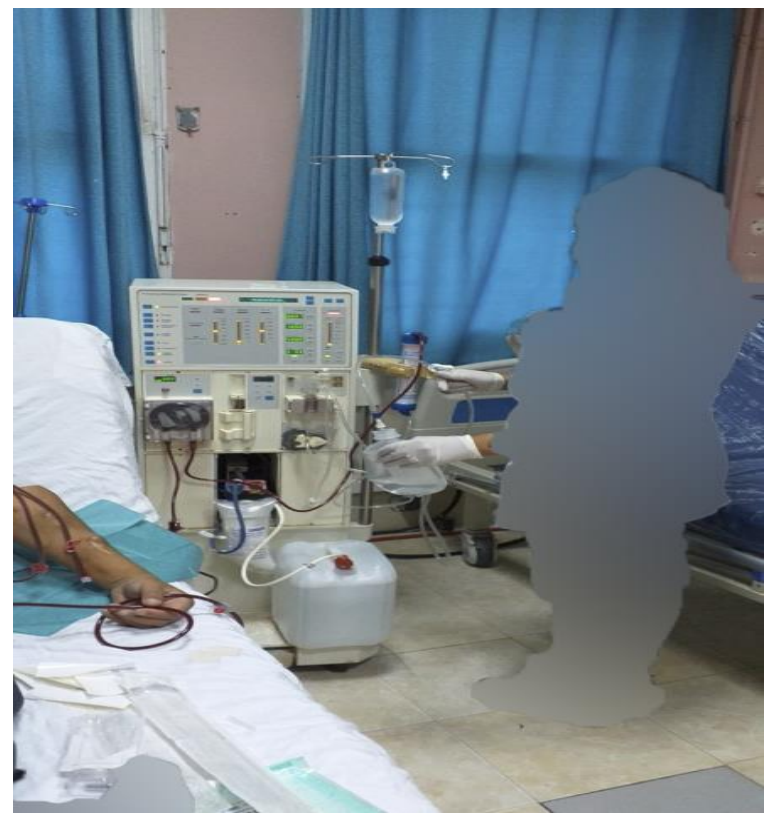

\section{HD session}

\section{Results}

In our hospital, in a study carried out on chronic hemodialysis patients during the year 2019, we identified 8 cases out of 87 patients infected with 
HVC, or $9 \%$. The average age is 48 years with extremes ranging from 31 years to 74 years? A male predominance: $75 \%$. Patients had been on dialysis for an average of 15 years with extremes ranging from 3 years to 32 years. Viral infection was discovered on average 12.5 years after the start of hemodialysis during a routine screening examination. In this series, the genotype $1 \mathrm{~b}$ was found in 2 cases $(25 \%)$. Seven patients were treated out of the eight HCV hemodialysis patients, ie $87.5 \%$ of the cases. Causal nephropathy was undetermined in $37 \%$ of cases, hereditary in $25 \%$ of cases, diabetic in $12.5 \%$ of cases, vascular and malformative in $12 \%$ of cases. The average pre-therapeutic viral load was $1,287,500 \mathrm{IU} / \mathrm{ml}$ with extremes ranging from $1020,000 \mathrm{IU} / \mathrm{ml}$ to $2,650,000 \mathrm{IU} / \mathrm{ml}$. serum alanine aminotransferase (ALT) increased $\geq 2$ times normal in one patient $(12.5 \%)$ and normal in the rest of the patients. All seven patients received dual therapy based on sofosbuvir 400mg and daclar $60 \mathrm{mg}$ for three months, with an early virological response and good tolerance.

\section{Risk Factors for Viral Transmission}

In a previous study, looking at the risk factors for HVC transmission, period between 2015 and 2018: 11 cases out of 134 hemodialysis patients infected with VHC: $8.2 \%$. Among these cases we noted the following factors, Blood transfusion: 3 cases $(27.2 \%)$, Surgery: 4 cases $(45.4 \%)$, Dental care: 2 cases (18\%), No cause: 2 cases (9\%) HCV antibody positive: $11 / 134$, seroprevalence : $8.2 \%$. PCR-viral RNA (11 patients): 10 patients (anti- HCV + / ARNVHC +), number of copies: Above 1.03x 1, 000,000 (100\%), number of Logs: Sup to 3.32 (100\%), and negative PCR: 01 patient, or VHC prevalence: $7.4 \%$ by PCR.

\section{Discussion}

Low rate observed in our center $(8.2 \%-9 \%)$, is explained by: preventive hygiene measures (gloves and disposable dialysis consumables, sterilization of dialysis generators between sessions ..., use of recombinant erythropoietin. The more sensitive third generation tests have significantly reduced the risk of false negatives PCR, the sensitivity of which is the most effective diagnostic test for patients with renal failure. Infection with $\mathrm{HCV}$ normally leads to increased serum alanine aminotransferase (ALT), and laboratory blood testing for ALT is used to screen for liver disease in the general population. This is not the case in chronic hemodialysis patients, however, this test has weak diagnostic value in ESRD patients because ALT tends to be below reference range in this patient group. The potential causes of this are vitamin B6 deficiency, presence of uremic toxins, or presence of blood components that absorb ultraviolet light [2]. In our cases reported in this series only one patient had an increase in ALT (25\%). One study identified HCV genotype $1 \mathrm{~b}$ as the most prevalent subtype in patients receiving HD or continuous ambulatory peritoneal dialysis in Turkey [1]. The genotype $1 \mathrm{~b}$ was found in 2 cases (25\%), the genotype study did not take place in all of these patients. Viral infection was discovered on average 12.5 years after the start of hemodialysis, during a routine screening examination in our study. This observation is already known in the literature, among factors reported in hemodilysed patients, such as, excessive exposure to blood and nosocomial transmission of HCV in hemodialysis units, and long dialysis duration are the main determinants of increased risk of $\mathrm{HCV}$ infection in the HD patient group[3[. The worldwide prevalence of HCV infection among HD patients varies widely, with estimates ranging from $5 \%$ to approximately $60 \%$ depending on geographic location (4-5). In 2002 , the prevalence of HCV infection across HD centers of the United States was approximately $8 \%$, nearly five times greater than that of the general population in that country [6,7]. In some European dialysis centers, the yearly incidence of $\mathrm{HCV}$ infection reportedly ranges from
$0.4 \%$ to $16.0 \%$ [8]. Anti-HCV prevalence among patients on chronic HD in the United States decreased from $10.4 \%$ in 1995 to $7.8 \%$ in 2002 [9]. Isolating-HCV-infected patients or using dedicated machines for such patients are not advocated, except as necessary during local outbreaks [8$10]$.

\section{Conclusion}

Hepatitis $\mathrm{C}$ virus related liver disease is a significant cause of morbidity and mortality in patients with end-stage renal disease (ESRD) who are treated with dialysis. Early diagnosis and treatment of HCV infection prior kidney transplantation prevent complications after transplantation and reduces mortality (11). Serologic testing has clearly demonstrated that $\mathrm{HCV}$ infection is highly prevalent among ESRD patients and is a serious cause of increased morbidity and mortality in this group. The excessive exposure to blood and blood products, nosocomial transmission of $\mathrm{HCV}$ in hemodialysis units, and long dialysis duration are the main determinants of increased risk of HCV infection in the hemodialysis patient group. In practice, $\mathrm{HCV}$ must be detected in hemodialysis patients by the search for HCV antibodies and, if in doubt, by HCV PCR. It is essential that each dialysis center carefully follows every $\mathrm{HCV}$-infected ESRD patient to determine viral load, do HCV genotyping, assess the extent of hepatic fibrosis, and establish optimal treatment strategies. Its treatment is mainly preventive based on compliance with universal hygiene rules, but also curative based on direct acting antivirals.

\section{References}

1. Selcuk H, Kanbay M, Korkmaz M, Gur G, Akcay A, Arslan H, Ozdemir N, Yilmaz U, Boyacioglu S. (2006). Distribution of $\mathrm{HCV}$ genotypes in patients with end-stage renal disease according to type of dialysis treatment. Dig Dis Sci. 51:14201425.

2. Tang S, Lai KN. (2005). Chronic viral hepatitis in hemodialysis patients. Hemodial Int. 9:169-179.

3. Goodkin DA, Bragg-Gresham JL, Koenig KG, Wolfe RA, Akiba T, Andreucci VE, Saito A, Rayner HC, Kurokawa K, Port FK. Association of comorbid conditions and mortality in hemodialysis patients in Europe, Japan, and the United States: the Dialysis Outcomes and Practice Patterns Study (DOPPS). J Am Soc Nephrol. 14:3270-3277.

4. HC, Greenwood RN, Akiba T, Young EW. (2003). Patterns of hepatitis $\mathrm{C}$ prevalence and seroconversion in hemodialysis units from three continents: the DOPPS. Kidney Int. 2004; 65:23352342.

5. Alavian SM, Kabir A, Ahmadi AB, Lankarani KB, Shahbabaie MA, Ahmadzad-Asl M. (2010). Hepatitis C infection in hemodialysis patients in Iran: a systematic review. Hemodial Int. 14:253-262.

6. Finelli L, Miller JT, Tokars JI, Alter MJ, Arduino MJ. National surveillance of dialysis-associated diseases in the United States, 2002. Semin Dial. 2002;18:52-61.

7. Patel PR, Thompson ND, Kallen AJ, Arduino MJ. (2010). Epidemiology, surveillance, and prevention of hepatitis $C$ virus infections in hemodialysis patients. Am J Kidney Dis. 56:371378

8. Zampieron A, Jayasekera H, Elseviers M, Lindley E, DeVos JY, Visser R, Harrington M. (2006). European study on epidemiology and management of hepatitis $\mathrm{C}$ virus (HCV) 
infection in the haemodialysis population. Part 3: prevalence and incidence. EDTNA ERCA J. 32:42-44.

9. Mangia A, Burra P, Ciancio A, Fagiuoli S, Guido M, Picciotto A, Fabrizi F. (2008). Hepatitis C infection in patients with chronic with chronic kidney disease. Int J Artif Organs. 31:1533.

10. Bianco A, Bova F, Nobile CG, Pileggi C, Pavia M. (2013). Healthcare workers and prevention of hepatitis $\mathrm{C}$ virus transmission: exploring knowledge, attitudes and evidencebased practices in hemodialysis units in Italy. BMC Infect Dis. 13:76.

11. Digdem Ozer Etik, Serkan Ocal, Ahmet Sedat Boyacioglu. (2015). Hepatitis $C$ infection in hemodialysis patients. A review World J Hepatol. 7(6): 885-895.
Ready to submit your research? Choose Auctores and benefit from:

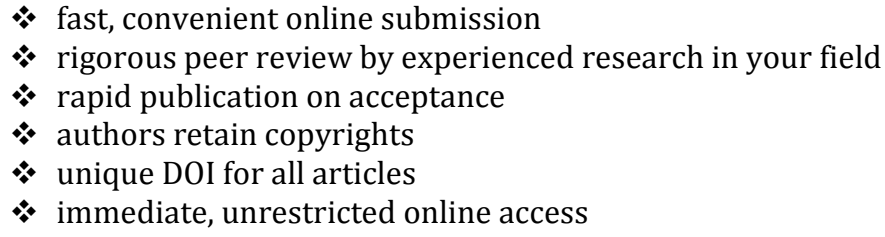

At Auctores, research is always in progress.

Learn more www.auctoresonline.org/journals/journal-of-clinical-casereports-and-studies 